\title{
HAK WARIS ANAK ANGKAT DALAM PESPEKTIF UNDANG - UNDANG DAN HUKUM ISLAM
}

\author{
Ahmad Alamuddin Yasin \\ Mahasiswa Pascasarjana IAIN Syekh Nurjati Cirebon \\ Email :ahmadalamuddin11@gmail.com
}

\begin{abstract}
Adoption of children has been carried out in ancient times in different ways in line with the legal system and legal feelings that live and develop in the community concerned. The issue of adoption or adoption has two dimensions at once, namely the social dimension which has the value of helping fellow human beings, and the legal dimension which has implications for the pattern of arrangements between adopted children, adoptive parents, and biological parents. This research method is a descriptive analysis that leads to normative legal research, with a research approach to legal systematics. Data collection tools were obtained from secondary data, namely by way of library research (library research). The data obtained were then analyzed using qualitative analysis. Based on the results of the research, it is concluded that based on Article 209 paragraphs 1 and 2 of the KHI, adopted children are entitled to a share of the inheritance of their adoptive parents in the form of a compulsory will, whether there is a will or no will. The article provides an understanding that adoptive children in the distribution of inheritance do not take place by mutual inheritance, but through compulsory wills which are not more than 1/3.
\end{abstract}

Keywords : adopted children, inheritance, Islamic law

\begin{abstract}
Abstrak
Pengangkatan anak telah dilakukan pada zaman dahulu dengan cara yang berbedabeda sejalan dengan sistem hukum dan perasaan hukum yang hidup dan berkembang pada masyarakat yang bersangkutan. Persoalan pengangkatan anak atau adopsi memiliki dua dimensi sekaligus, yaitu dimensi sosial kemasyarakatan yang memiliki nilai membantu sesama umat manusia dan dimensi hukum yang berimplikasi pada pola pengaturan antara anak angkat, orang tua angkat dan orang tua kandungnya. Metode penelitian ini bersifat deskriptif analisis yang mengarah pada penelitian hukum normatif, dengan pendekatan penelitian terhadap sistematika hukum. Alat pengumpul data diperoleh dari data sekunder yaitu dengan dengan cara studi pustaka (library research). Data yang diperoleh kemudian dianalisis dengan menggunakan analisis kualitatif. Berdasarkan hasil penelitian disimpulkan bahwa, berdasarkan Pasal 209 ayat 1 dan $2 \mathrm{KHI}$, anak angkat berhak mendapatkan bagian dari harta warisan orang tua angkatnya berupa wasiat wajibah, baik ada wasiat maupun tidak ada wasiat. Pasal tersebut memberi pemahaman bahwa anak angkat dalam pembagian harta peninggalan tidak berlangsung dengan jalan saling mewarisi, tetapi melalui wasiat wajibah yang tidak lebih dari 1/3.
\end{abstract}

Kata Kunci: anak angkat, waris, hukum islam 


\section{Pendahuluan}

Bagian pendahuluan Salah satu tujuan dari perkawinan adalah untuk melahirkan dan menciptakan kesinambungan keturunan. Secara naluriyah, pasangan suami istri pada umumnya sangat mendambakan akan kehadiran seorang anak yang akan menjadi pewaris keturunan, tempat curahan kasih sayang dan perekat tali perkawinan. Perkawinan tanpa kehadiran seorang anak akan terasa gersang dan tidak lengkap, karena kehadiran anak dalam rumah tangga memiliki banyak makna.

Sedangkan Imam Al-Ghazali (2010:28) memaparkan beberapa tujuan pernikahan yakni : Untuk memperoleh keturunan yang sah, yang akan melangsungkan serta mengembangkan keturunan suku-suku bangsa manusia, menumbuhkan kesungguhan berusaha untuk mencari rizki yang halal dan memperbesar rasa tanggung jawab.

Menyelamatkan harta terhadap keturunan dalam agama Islam disebut dengan waris dalam hal ini tentu dengan cara memilih perempuan yang subur sebagaimana dalam hadits (Sulaiman, 2005:202) :

كان رسول الله صلى الله عليه وسلم يقول : تزوجوا الودود الولود فإني : مكاثر بكم الأمم يوم القيامة

Artinya : " nikahilah wanita yang penyanyang lagi subur, karena aku berbangga dengan jumlah umat yang banyak di depan umat-umat lainnya pada hari kiamat".

Secara realitas, banyak dari pasangan suami istri yang ternyata belum berhasil mendapatkan keturunan meskipun hanya dengan seorang anak. Hal ini bisa saja terjadi baik ditinjau dari sudut medis maupun agama. Hal ini bisa ditempuh dengan cara melakukan adopsi, yakni orang tua kandung merelakan penyerahan anaknya kepada pasangan yang belum mempunyai keturunan untuk dijadikan anak angkat bagi mereka. Dengan demikian akan terjadi peralihan tanggung jawab dari mereka yang kurang mampu kepada mereka yang lebih mampu untuk mendidik dan membesarkan anak tersebut.

Pada masa Jāhiliyah, pengangkatan anak merupakan hal yang istimewa, karena masyarakat Jāhiliyah pada saat itu menghukumi anak angkat sama dengan anak kandung sendiri, terlebih lagi bagi anak angkat yang berjenis kelamin lakilaki, maka akan lebih mendapatkan tempat yang terhormat, dari pada anak angkat yang berjenis kelamin perempuan ataupun anak kecil. Istilah tabannī di zaman ini, barangkali yang bisa menjelaskan akan supremasi anak angkat. Mereka menetapkan hukum putusnya hubungan nasab anak angkat dengan orang tua kandungnya untuk kemudian dihubungkan kepada orang tua angkatnya (Yani, 2016: 5).

Munculnya perbedaan perspektif, terutama hukum Islam dan hukum Perdata yang berlaku di Indonesia dalam memandang status anak angkat dan implikasinya terhadap perkara kewarisan ini menjadi suatu hal yang menarik untuk diteliti. Secara sosiologis, fenomena pengangkatan anak atau adopsi telah memberikan makna tersendiri, berupa adanya peralihan tanggung jawab dengan berbagai motivasi dari orang tua kandungnya kepada orang tua angkat, untuk mendidik dan membesarkan anak angkat. Di pihak lain, perbuatan tersebut telah melahirkan sederetan ketentuan hukum baru, terutama yang berhubungan 
dengan ketentuan perwarisan. Dalam penelitian ini, status kewarisan anak angkat dalam hubungannya dengan orang tua angkat menjadi penting untuk dibahas.

Masalah yang terjadi, sering sekali orang yang tidak memiliki anak, ia mengangkat anak angkat dengan banyak tujuan diantaranya untuk mengurusinya ketika ia sakit. Namun anak angkat yang susah payah mengurusi ayah angkatnya dia tidak mendapat hak apa apa dalam hak kewarisan agama sehingga yang mendapatkan waris itu adalah keluarga dari pihak keluarga ataupun lainnya yang dalam hal ini tidak tahu menahu bahkan tidak peduli ketika orang tersebut sakit. Solusi hal ini adalah dengan wasiat baik secara hukum agama maupun secara aturan yang ada.

Adapun tujuan penelitian ini adala merumuskan bagaimana konsep hak waris anak angkat dalam perspektif perundangundangan, bagaimana konsep kewarisan anak angkat dalam pandangan hukum islam,bagaimana perbandingan antara undang-undang dan hukum islam tentang hak waris anak angkat.

\section{Pengertian Anak Angkat}

Istilah pengangkatan anak dalam Islam disebut at-tabaňy; balanda; adoptie/adopteren, artinya "mengambil anak orang lain untuk dijadikan anak sendiri”( Mahmud, 1991: 27).

Nama lain dari anak angkat adalah adopsi, dalam Kamus Besar Bahasa Indonesia (2000:17) adopsi diartikan sebagai pengangkatan anak orang lain sebagai anak sendiri. Jadi, mengadopsi berarti mengambil (mengangkat) anak orang lain secara sah menjadi anak sendiri.

\section{Prosedur Pengangkatan Anak}

Surat Edaran Mahkamah Agung No 6 tahun 1983 mengatur syarat calon orang tua angkat bagi anak antar negara:

1)Berstatus kawin dan berumur minimal 25 tahun atau maksimal 45 tahun

2)Pada saat mengajukan permohonan sekurang-kurangnya sudah kawin 5 tahun, dengan mengutamakan keadaan:

a) Tidak mungkin mempunyai anak (surat keterangan dokter kebidanan, dokter ahli)

b) Belum mempunyai anak

c) Mempunyai anak kandung seorang

d) Mempunyai anak angkat seorang dan tidak mempunyai anak kandung

e) Dalam keadaan mampu ekonomi berdasarkan surat keterangan pejabat yang berwenang serendahrendahnya lurah atau kepala desa setempat.

f) Berkelakuan baik berdasarkan keterangan Polisi Republik Indonesia.

g) Dalam keadaan sehat jasmani dan rohani berdasarkan surat keterangan dokter pemerintah

h) Mengajukan pernyataan tertulis bahwa pengangkatan anak sematamata untuk kepentingan kesejahteraan anak

\section{Pengertian Waris}

Kata waris berasal dari bahasa Arab - ورث يرث-ورثا yang berarti mewarisi harta pusaka (Munawwir, 1984:1655). mewarisi harta pusaka. Orang yang meninggalkan harta waris disebut dengan مورث yang menerima 
harta warist disebut وارث, sedangkan harta warisannya disebut ميراث. Keterangan tersebut dapat disimpilkan bahwa waris menurut bahasa adalah berpindahnya sesuatu dari seseorang kepada orang lain, atau dari suatu kaum kepada kaum yang lain, baik berupa harta, ilmu, keluhuran, atau kemuliaan.

Dalam kamus hukum dijelaskan bahwa waris adalah orang yang menggantikan kedudukan si meninggal, mengoper semua hak kewajiban hukum si meninggal (Subekti, 1982:112).

Selanjutnya waris menurut istilah adalah berpindahnya hak milik dari mayit kepada ahli warisnya yang hidup, baik yang ditinggalkan itu berupa harta, kebun atau yang lainnya. Faraidh secara syariat adalah bagian yang ditentukan untuk ahli waris disebut pulauntuk suatu penamaan ilmu yakni ilmu Faraidh atau ilmu Waris."

Hukum Islam telah menerangkan dan mengatur hal-hal ketentuan yang berkaitan dengan pembagian harta warisan dengan aturan yang sangat adil sesuai dengan ketentuan yang terdapat dalam AlQurean, dalam hukum waris ini telah ditetapkan dengan rinci bagian masingmasing ahli waris baik laki-laki ataupun perempuan mulai dari bapak, ibu, kakek, nenek, suami, istri, anak, saudara, dan seterusnya. Adapun ketetapan waris dijelaskan pula dalam Hadis. Hukum warislah yang dijelaskan secara terperinci dalam Al-Qur'an sebab waris merupakan salah satu bentuk kepemilikan yang legal dalam Islam ataupun dalam Negara serta dibenarkan adanya oleh Allah SWT (Halid, 2004:14).

\section{Metode}

Penelitian ini menggunakan Hukum Normatif yaitu penelitian hukum yang mengkaji hukum tertulis dari berbagai aspek, yaitu aspek teori, sejarah, filosofi, perbandingan, serta penjelasan umum dan pasal demi pasal formalitas dan kekuatan mengikat suatu undang-undang dan bahasa hukum yang digunakan. Sementara itu jika dilihat dari sumber-sumber penelitiannya, penelitian ini bisa dikategorikan penelitian kepustakaan (Library Research).

Adapun pembahasan dalam penelitian ini akan menggunakan metode diskriptif (Descriptive Method), yakni memaparkan secara jelas dari berbagai permasalahan yang diteliti, setelah sebelumnya menganalisis dengan metode analisis komparatif. Analisis komparatif adalah analisa dengan menggunakan perbandingan, yakni perbandingan antara undang-undang dan hukum Islam.

Penelitian ini juga akan mengarah ke kajian pustaka, yakni penelitian melalui pendapat-pendapat para pakar yang dikutip oleh penulisan, sebagai sumber dan perbandingan.

\section{Hasil dan Pembahasan}

\section{Hak Waris Anak Angkat Menurut Undang-Undang \\ Dalam putusan Pengadilan Agama} Nomor: 0056/Pdt.P/2017/Pa tanggal 17 Maret 2017. Menetapkan bahwasannya bagian masing-masing ahli waris dan penerima wasiat wajibah atas harta peninggalan almarhum yang notabennya tidak memiliki ahli waris kecuali hanya istrinya adalah pemohon I yaitu istrinya sebagai ahli waris mendapat bagian $2 / 3$ dari harta sebagaimana tersebut fakta hukum, Pemohon II dan III yang stausnya sebagai anak angkat sebagai penerima 
wasiat wajibah, bersama-sama mendapatkan wasiat wajibah sebanyak $1 / 3$ dari harta sebagaimana tersebut fakta hukum;

\section{Hak Waris Anak Angkat Menurut Hukum Islam}

Pada zaman jahiliyah seseorang yang mengangkat anak dan mengatakan انت ابني ارثك ونرثنى “ kepada anak angkatnya “ (Engkau anakku, saya mewarisimu dan engkau mewarisi saya). Setelah itu anak tersebut menjadi anak kandung dan berlaku hak-hak yang terkait dengannya, seperti tentang kewarisan, nikâh, thalâk, dan hubungan persemedanan. Kemudian Allah swt. membatalkan tradisi ini, dan Nabi pun yang sebelumnya mengikuti tradisi Jahiliyah dengan menamakan Zaid bin Muhammad menjadi Zaid bin Haritsah, di mana Haritsah adalah ayah kandungnya sendiri (As-Shabuni:235).

Dalam tradisi Islam salah satu bentuk pengangkatan anak ayng dijustifikasi Islam adalah bahwa seorang mengambil anak orang lain untuk diperlakukan seperti anak kandung sendiri dalam hal pemberian kasih sayang, nafkah, pendidikan, dan keperluan lainnya. Namun, secara hukum anak itu bukanlah anaknya sendiri. Tabannî semacam ini adalah perbuatan yang pantas dikerjakan oleh orang-orang yang luas rezekinya, namun ia tidak dikaruniai anak. Mereka melihat bahwa pengambilan anak ini merupakan bentuk taqarrub (pendekatan diri) kepada Allah SWT. dengan mendidik anak fakir yang tidak dapat merasakan kasih sayang orang tuanya atau ayahnya dan tidak mampu membiayai pendidikan dan pengajaran anaknya. Tentu saja, perbuatan ini termasuk ke dalam amal yang dicintai syara' dan merupakan bentuk dakwah yang diberi pahala. Dalam kaitan ini, syara' sendiri membuka pintu bagi orang kaya untuk memberi wasiat kepada anak angkatnya dari sebagian tirkah-nya sebagai pemenuhan keperluan masa depannya sehingga ia merasakan ketenangan hidup dan jauh dari hidup sengsara (Syaltout, 1999:292).

Dari keterangan di atas, dapat dipahami bahwa seorang anak yang diangkat karena motif sosial dan tidak diberi status anak kandung, orang tua angkatnya boleh orang tua angkatnya memberikan sebagian hartanya melalui wasiat.

Dalam wasiat ada ketentuan yang berbeda, di mana harta yang diwasiatkan tidak boleh lebih sepertiga, jika pemberi wasiat mempunyai ahli waris. Hal ini didasarkan atas ijma ulama dan hadits yang diriwayatkan oleh Abi Waqqash, di mana ketika ia hendak berwasiat, ia bertanya lebih dahulu kepada Rasulullah apakah dirinya akan mewasiatkan hartanya sebanyak 1/3 (sepertiga), lalu Rasulullah saw. bersabda:

...الثلث, والثلث كثير. إنك ان تذر ورثتك اغنياء خيرمن ان تذرهم

$$
\text { عالة تتكقفون الناس... }
$$

Sepertiga saja dan sepertiga itu banyak. Sesungguhnya, meninggalkan ahli warismu kaya lebih baik ketimbang meninggalkan mereka dalam keadaan miskin dan meminta-minta kepada orang lain. (Al-Syaukani: 7).

Apabila pemberi wasiat dengan adanya ahli waris memberi lebih dari $1 / 3$ (sepertiga) , maka tangguhkan kelebihannya atas persetujuan ahli waris.Jika mereka setuju, maka kelebihan harta tersebut tetap menjadi wasiat. Persetujuan ahli waris ini dapat dilangsungkan apabila memenuhi dua 
syarat, yaitu: persetuan tersebut dilaksanakan setelah matinya pemberi wasiat dan persetujuan itu dilakukan oleh ahli waris yang sudah akil baligh dan mengetahui jumlah harta yang diwasiatkan. Apabila sebagian ahli waris saja yang menyetujui, sedangkan lainnya tidak menyetujui, maka yang terjadi adalah hanya terbatas pada benda yang menjadi bagian yang menyetujuinya. Sedangkan bagian yang tidak menyetujuinya adalah batal.

Berbeda dengan hal di atas, apabila pemberi wasiat tidak punya ahli waris, maka, menurut Abu Hanifah, kelebihan dari dari 1/3 (sepertiga) harta itu sah dan harus dilangsungkan sekalipun sampai menghabiskan seluruh harta (Zuhaili, 2012:101). Tersebab kendala pelaksanaan wasiat lebih dari $1 / 3$ adalah terkait dengan ahli waris, jika ahli waris itu tidak ada, maka tidak seorang pun yang mempunyai hak dalam hal ini. Berbeda dengan pendapat ini, ulama' Malikiyah, Hanabilah, dan Syafi'iyah berpendapat dalam hal wasiat lebih dari 1/3 dan tidak ada ahli warisnya, maka wasiat tersebut batal, karena kelebihan harta itu adalah harta milik orang-orang Islam, dan oleh karena itu tidak ada yang dapat melaksanakan kehendak pemberi wasiat (An-Nawawi: 450).

Dari uraian tersebut, bisa dikatakan bahwa peralihan hak milik dari seseorang kepada orang lain yang bukan ahli warisnya, dapat digunakan cara wasiat dengan ketentuan-ketentuan di atas. Di samping itu, ia juga bisa ditempuh dengan cara hibah, yakni pemberian langsung kepada anak angkat pada masa orang tua angkat masih hidup. Cara lainnya yang diatur oleh Islam adalah melalui wasiat wajibah, yaitu ketentuan yang menyatakan calon pewaris wajib membuat wasiat mengenai bagian harta peninggalannya. Dalam ketentuan Kompilasi Hukum Islam (KHI), wasiat wajibah itu diberikan kepada anak angkat (Ali, 1991:280).

\section{Analisis Undang-Undang Dan Hukum Islam Terhadap Hak Waris Anak Angkat}

Undang-undang dan Hukum Islam, tidak menganggap adanya hak Waris namun lebih ke arah wasiat. Penulis menamakan hal ini dengan waris, karena banyak dalil yang menganggap sama antara wasiat dan waris.

Dalam surat Annisa Ayat 11 menjelaskan bahwa Allah SWT. menuliskan kata wasiat pada firman-Nya untuk dalil bagian waris. Menurut penulis, ayat Al-Qur'an tersebut bisa dijadikan dalil diperbolehkannya wasiat kepada ahli waris. Adapun makna hadis لاوصية لوارث adalah: Apabila ahli waris yang lain tidak menyetujui menurut pendapat selain Madzhab Maliki. Adapun Madzhab Maliki menganggap batal wasiat terhadap ahli waris meskipun ahli waris yang lainnya menyetujuiny (Zuhaili, 2012:48). Bahkan kelompok Syi'ah Imamiyah, Syi'ah Zaidiyah, dan Syi'ah Isma'iliyah, memperbolehkan adanya wasiat kepada ahli waris meskipun ahli waris yang lain tidak menyepakatinya. Dalil mereka adalah surah Al-Baqarah ayat 108 yang artinya apakah kamu menghendaki untuk meminta kepada Rasul kamu seperti Bani Israil meminta kepada Musa pada jaman dahulu? dan Barangsiapa yang menukar iman dengan kekafiran, Maka sungguh orang itu telah sesat dari jalan yang lurus.

Alternatif pemecahan masalah tentang bagian warisan bagi anak angkat 
ini kiranya tidak jauh dari ajaran Islam, karena apabila anak angkat tidak diberi bagian dari harta peninggalan orang tua angkatnya maka akan menimbulkan kerenggangan hubungan persaudaraan dalam kekeluargaan antara anak angkat dengan orang tua angkatnya, atau dengan kata lain akan menimbulkan kemadharatan baginya. Sedangkan Islam tidak menghendaki adanya kesulitan dan kemadharatan bagi penganutnya.

Dengan demikian dapat ditarik kesimpulan bahwa oleh karena anak angkat tidak termasuk golongan orang yang menerima warisat dari orang tua angkatnya, maka hal ini mereka akan menerima harta warisan melalui wasiat wajibah. Dan sebagai dasar yang bisa digunakan untuk dijadikan aturan mengenai wasiat wajibah terhadap anak angkat atau sebaliknya adalah Kompilasi Hukum Islam yang mana itu hanyalah melalui pertimbangan maslahah mursalah.

Dari uraian Ibnu Hazm didalam kitabnya Al-Muhalla Jilid 9 tampak bahwa kedua orang tua dan kerabat yang tidak mewarisi, salah satunya disebabkan tidak beragama Islam (non muslim) wajib diberi wasiat. Yang dimaksud kerabat menurut Ibnu Hazm adalah orang yang apabila ditelusuri masih ada hubungan darah dari pihak ayah atau ibunya, atau semua keturunan yang masih memiliki hubungan nasab dengan ayah dan ibu samapi terus ke bawah.

Jadi pengertian wasiat wajibah yang dimaksudkan oleh Ibnu Hazm adalah pemberian kepemilikan harta dari pewasiat baik harta yang ditinggalkan tersebut banyak ataupun sedikit yang wajib diberikan kepada orang tua atau kerabat yang sudah tidak memiliki hak waris baik yang sebabkan oleh karena orang tua atau kerabatnya telah menjadi budak atau kufur (non muslim), yang akan berlaku setelah pewasiat meninggal dunia.

Menurut Ibnu Hazm (Jilid 9:417) hukum asal dari wasiat adalah wajib dilakukan oleh orang yang mempunyai harta baik banyak maupun sedikit. Pendapat ini berasal dari pendapat Abdullah bin Umar thalkhah Zabair, Abdullah bin Aufa, Thowus, as-Sya ${ }^{e c}$ bi dan Az-Zuhri. Mereka beralasan dengan arti dzahir ayat 180 surah al-Baqarah pada kata كتب yang berarti فرض yang diartikan dengan kewajiban oleh karena itu maka hukum wasiat adalah wajib.

Dalam kitabnya al-Muhalla Ibnu Hazm berpendapat bahwa wajib berwasiat kepada kaum kerabat yang tidak mendapatkan bahagian harta pusaka. Karena penurunan ayat pusaka yang menerangkan hak faraid bagi waris-waris tidak menassakhkan kewajiban berwasiat bahkan peruntukan ayat wasiat tersebut dikhususkan bagi ahli-ahli waris yang tidak mendapat pusaka disebabkan oleh halangan-halangan tertentu. Dengan kata lain, berwasiat kepada ahli keluarga yang tidak mendapat pusaka merupakan kewajiban yang perlu dilaksanakan. Dalam hal ini Ibnu Hazm menegaskan bahwa kewajiban itu tidak gugur meskipun selepas kematian seseorang muslim dan menjadi kewajiban kepada waris atau pentadbir harta untuk menyempurnakan tanggung jawab tersebut menurut kadar yang berpatutan tampa menimbulkan kesusahan kepada waris-waris yang dtinggalkan.

Ibnu Hazm (Jilid 9:312) juga menguatkan kesimpulannya dengan beberapa hadist lain: 
ماحق امرئ مسلم له شيئ يوصى فيه بييت ليلتين إلا

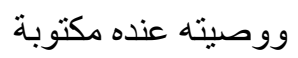

Artinya: Adalah dosa seorang muslim yang mempunyai sesuatu guna diwasiatkan lantas tidur dua malam berturut-turut, kecuali wasiatnya itu sudah tertulis.

Jumhur menolak hadis ini dengan alasan ada perubahan matan. Seharusnya berbunyi: له شيئ يريد أن يوصى فيه

Artinya: Adalah dosa seorang muslim yang ingin mewasiatkan lantas tidur. Setelah itu jumhur menguatkan adanya perubahan matan tersebut dengan kenyataan, bahwa rawi-rawi Hadis tidak ada yang melakukan wasiat. Ibn Hazm (Jilid 9:312) membantah kritikan ini karena ada beberapa sanad yang memenuhi syarat, yang tidak disinggung oleh jumhur.

Menurut Wahbah Al-Zuhaili, bahwa kata

الوصيةpada penerapannya digunakan untuk penyebutan sesuatu hak yang ketetapannya disandarkan atas waktu tertentu, baik dalam keadaan hidup orang yang melakukannya atau setelah kematiannya. Kemudian term ini dikhususkan untuk penyebutan sesuatu hak yang ketetapannya disandarkan atau waktu setelah kematian orang yang melakukan wasiat itu (الموصى). jadi analisis bahasa, maka ferm wasiat berarti membuat pesan atau wasiat (الإيصاء) atau juga dipakai untuk sebutan atas sesuatu yang diwasiatkan atau diperankan (الموصى به) (Zuhaili, 2012:33). Disini akan penulis kemukakan beberapa pengetian secara terminologi lainya tentang wasiat yaitu :

a. Madzhab Hanafi memberikan definisidefinisi wasiat sebagai pemberian hak memiliki sesuatu secara sukarela yang pelak pelaksanaannya ditangguhkan sampai adanya peristiwa kematian orang yang memberikan baik sesuatu yang diwasiatkan itu berupa benda maupun manfaat (Zuhaili, 2012:87).

b. Madzhab Maliki, Syafi'i dan Hambali memberikan definisi wasiat sebagai sesuatu perkataan atau transaksi yang mengharuskan orang yang menerima wasiat (الموصى له) berhak menerima 1/3 (sepertiga) dari harta peninggalan pewasiat (الموصى) setelah sepeninggalnya atau yang mengharuskan penggantian hak $1 / 3$ harta pewasiat kepada penerima wasiat, sepeninggalnya (Zuhaili, 2012:92).

c. Sayid Sabiq dalam Fiqh Al-Sunnahnya memberikan definisi yang hampir sama dengan Hanafiyah tentang wasiat ini, yaitu sebagai tindakan seseorang yang memberikan haknya kepada orang lain untuk memiliki sesuatu baik merupakan kebendaan maupun manfaat secara sukarela tanpa imbalan yang pelaksanaannya ditangguhkan sampai terjadi kematian orang yang menyatakan wasiat tersebut (Sabiq, 1983:583).

d. Dalam Kompilasi Hukum Islam, terdapat pengertian wasiat dalam pasal 171 huruf (f) yaitu pemberian suatu benda dari pewaris kepada orang lain atau lembaga yang berlaku setelah pewaris meninggal dunia.

Dari paparan diatas, dapat dibuat gambaran tentang wasiat yang selanjutnya disebut dengan hak waris anak angkat dengan beberapa unsur yaitu:

1. Pewasiat, penerima wasiat, harta

Dalam hal ini pewasiat adalah orang tua angkat, penerima wasiat adalah anak angkat dan harta adalah tirkah.

2. Peninggalan dibatasi dengan $1 / 3$ 
Menurut madzhab Syafi'i, Maliki, dan Hambali bahwa harta peninggalan yang diwasiatkan tidak boleh lebih dari 1/3 meskipun pewasiat tidak memiliki ahli waris, sisa dari harta tersebut akan dimasukkan pada kas negara.

Namun, madzhab Hanafi seperti yang penulis paparkan pada bab sebelumnya bahwa, jika pewasiat tidak memiliki ahli waris maka penerima wasiat boleh mendapatkan 1/3 dari tirkah bahkan dengan seluruh hartanya.

Hal ini, sangat tepat sekali dengan kondisi sosiologis yang ada di Indonesia, karena indonesia belum memiliki badan kas negara secara resmi.

3. Harta peninggalan tersebut baik berupa materi maupun manfaat

4. Pelaksanaannya setelah kematian pewasiat

\section{Kesimpulan}

Untuk melindungi hak anak angkat yang mana tidak ada lagi ahli waris selain anak angkat, perlu ditinjau kembali perundang-undangan yang menetapkan bahwasanya anak angkat hanya mendapatkan 1/3 dari harta warisan yang kemudian selebihnya disalurkan ke baitulmal. Karena hingga saat ini belum ada badan khusus yang telah dilegalkan oleh pemerintah yang menangani hal tersebut.

Dengan adanya pendapat madzhab hanbillah yang mengatakan anak angkat dapat menerima harta warisan lebih dari 1/3 bahkan seluruhnya dapat menjadi solusi atas masalah tersebut, atas tinjauan kemaslahatan yang nantinya beribas kepada anak angkat tersebut.

\section{Daftar Pustaka}

Al- Nawawi, Al-Muhadzab, Juz 1. Beirut : Dar al-Fikr, t.th.

Al-Ghazali, Muhammad. (2010). Ihya Ulum ad-Din, Jilid 2. Mesir : Dar atTaqwa.

Ali, Muhammad Daud. Hukum Islam; Pengantar Ilmu Hukum dan Tata Hukum Islam di Indonesia (Jakarta: Raja Grafindo Persada. 1991)

Al-Shabuni, Muhammad Alî. Tafsir Ayat al-Ahkam, Juz 2 (Makkah : Dar alFikr, t.th

Al-Syaukani, Irsyad al-Fuhul, Juz 6. Beirut: Dar al-Fikr, t.th.

Halid, Abdul Hakim. (2004). AhkamulMawarits Fi-Fiqhil-Islam, Hukum Waris, Terjemah oleh Fathurrahman dan Addys Aldisar. Jakarta: Senayan Abadi Publising.

Hazm, Ibnu. Al-Muhalla. Jilid. 9; Beriut: Dar Al-Fikr.

Kamus Besar Bahasa Indonesia. (2000). Jakarta: Bumi Aksara

Munawwir, Achmad Warson. (1984). Kamus al-Munawwir Arab Indonesia Terlengkap. Yogyakarta: Pustaka Progresif.

Subekti dkk. (1982). Kamus Hukum. Jakarta: P.T Pradnya Paramita, 1982)

Sulaiman bin al-Asy'ats ( Imam Abu Daud ). (2005). Sunan Abu daud, Jilid 2. Beirut : Dar al-Fikr.

Syaltout,Mahmud. (1991). Al-Fatawa. Kairo: Dar Al-Qalam, 1999.

Yani, Achmad. (2016). Faraidh \& Mawaris. Jakarta : Kencana

Zuhaili, Wahbah. (2012). Mausu'ah AlFiqhi Al-Islamy Wa Al-Qadhaya AlMu'ashirah, Jilid ke-9. Damaskus: Dar Al Fikr 